\title{
Quality of minimally processed guava with different types of cut, sanification and packing
}

\author{
Qualidade de goiaba processada minimamente com diferentes tipos de corte, sanificação e embalagem
}

\author{
Marilene Silva LIMA ${ }^{1 *}$, Edleide Maria Freitas PIRES ${ }^{1}$, \\ Maria Inês Sucupira MACIEL ${ }^{2}$, Vanusa Alves OLIVEIRA ${ }^{1}$
}

\begin{abstract}
The purpose of this project was to evaluate the sanitization effect on the quality of minimally processed guava. Initially, research was carried out with consumers in a supermarket to verify preferences of packaging for guava. Following this, the guava cv. Paluma underwent two sanitization sequences using dehydrated sodium dichloroisocyanurate compound, in $50 \mathrm{ppm}$ concentration, sanitization prior to (S1) and after (S2) being cut; removal of excess water; conditioning in PET packaging and PS-PVC and storage at $3{ }^{\circ} \mathrm{C} \pm 1{ }^{\circ} \mathrm{C}$. Physicochemical analysis - [pH, total soluble solids (SST), total labeled acidity (ATT), ascorbic acid (AA), total sugars (AT) and reducers (AR)], textural sensorial and microbiological analyses were used to monitor the quality of the products. The consumers preferred the guava cut in halves with pulp and packed in PET, although this packaging promoted condensation of water vapor on the inner surface of the lid, compromising the appearance of the product. The two sanitization sequences and the two kinds of packaging did not significantly affect the pH, SST, ATT, SST/ATT, texture and AA values. The AT and AR tenors increased significantly in the MP guavas stored in the PS-PVC package. Both sanitizations were efficient in the bacterial control of the indicators of the hygienic-sanitary conditions, although the S1 sanitization proved to be more efficient in the control of autochthonous aerobic microbiota (aerobic mesophylic microorganisms). It can be concluded that guava cv. Paluma packed in PS-PVC can be conserved for 6 days when stored at $3{ }^{\circ} \mathrm{C}$.

Keywords: minimally processed; guava; quality; sanitization.
\end{abstract}

\section{Resumo}

O objetivo deste trabalho foi avaliar o efeito da sanitização sobre a qualidade de goiabas minimamente processadas. Inicialmente, foi realizada uma pesquisa com consumidores em um supermercado para verificar a preferência em relação a tipos de cortes e tipos de embalagens para goiabas. Após essa etapa, goiabas cv. Paluma passaram por duas sequências de sanificação com o composto clorado orgânico dicloro isocianurato de sódio di-hidratado, na concentração de 50 ppm: sanificação antes (S1) e depois do corte (S2); retirada do excesso d'água; acondicionamento em embalagens PET e PS-PVC e armazenamento a $3{ }^{\circ} \mathrm{C} \pm 1{ }^{\circ} \mathrm{C}$. Análises físico-químicas [pH, sólidos solúveis totais (SST), acidez total titulável (ATT), ácido ascórbico (AA), açúcares totais (AT) e redutores (AR)], texturais, sensoriais e microbiológicas foram efetuadas para monitorar a qualidade do produto. Os consumidores preferiram a goiaba cortada na metade equatorial com polpa e embalada em PET, entretanto esta embalagem promoveu a condensação de vapor de água na superfície interna da tampa comprometendo a aparência do produto. As duas sequências de sanificação e os dois tipos de embalagens não influenciaram significativamente os valores de pH, SST, ATT, SST/ATT, textura e AA. Os teores de AT e AR aumentaram significativamente nas goiabas MP armazenadas na embalagem PS-PVC. Ambas as sanificações foram eficazes no controle das bactérias indicadoras das condições higiênico-sanitárias, entretanto a sanificação S1 mostrou-se mais eficaz no controle da microbiota autóctone (microrganismos aeróbios mesofilos viáveis). Pode-se concluir que goiabas da cv. Paluma embaladas em PS-PVC podem ser conservadas por 6 dias quando armazenadas a $3{ }^{\circ} \mathrm{C}$.

Palavras-chave: minimamente processado; goiaba; qualidade; sanitização.

\section{Introduction}

Consumer demand for fresh-cut tropical products is increasing rapidly in the world market (KADER, 2006). In the last decade the population's consumption preferences changed drastically, creating a growing demand for minimally processed agricultural products, sustained by the preservation of freshness, nutritional quality, and the convenience offered by these products. Furthermore, the search for healthier and balanced food is increasing daily (ANTONIOLLI et al., 2004; CARVALHO; LIMA, 2000; ROSA; CARVALHO, 2000).

The minimal processing of fruits and groceries is defined as the process that eliminates non-edible parts, such as rinds, stems and seeds, followed by cutting, washing, classification, sanitization, centrifugation, packaging and storage, possibly

Recebido para publicação em 12/3/2008

Aceito para publicação em 17/11/2009 (003209)

${ }^{1}$ Departamento de Nutrição, Universidade Federal de Pernambuco - UFPE, Recife - PE, Brasil, E-mail: efpi@uol.com.br

${ }^{2}$ Ciências Domésticas, Universidade Federal Rural de Pernambuco - UFRPE, Recife - PE, Brasil

${ }^{*}$ A quem a correspondência deve ser enviada 
including low levels of irradiation and whitening, making them ready-to-eat without losing their freshness, with good quality and degree of sanitization. These processes, however, interfere with physical, chemical and biological aspects that cause product degradation, since the processed vegetal physiology is essentially similar to that of damaged vegetal tissue, differing from the normal processes where the tissues remain viable (DURIGAN, 2000; AHVENAINEM, 1996; BRECHT, 1995).

Minimal processing makes the vegetables more susceptible to perish when compared to the original product, causing an increase in respiration rate, generating more chemical reactions, which lead to faster degeneration and to increased water evaporation with much quicker wilting or withering (DI PENTIMA et al., 1996).

In addition to these Physicochemical modifications, the products are also susceptible to microbial contamination acquired during manipulations, packaging and storage, which can increase the type and number of microorganisms present, and allow contamination by opportunistic pathogenic microorganisms, given that the tissue damage caused to minimally processed vegetables can make the nutrients accessible to them (ROSA; CARVALHO, 2000). Several treatments have been studied to maintain quality and extend shelf-life of fresh-cut fruit (ROJAS-GRAÜ; TAPIA; MARTIN-BELLOSO, 2007).

Washing the vegetables with antimicrobiotic solutions is required for the effective control of the microorganisms (ANTONIOLLI et al., 2004). The chlorine of organic origin most widely, due to the cost factor, is sodium hypochlorite, although it is believed that the subproduct of chloration, trihalomethanes (THMs), is potentially carcinogenic. In addition, its presence is a sign of the likely presence of other chlorinated organics (chlorinated acetic acid, haloacetonitriles, chloropicrin, chlorine phenols and chloropropane) more dangerous than the THMs (MACÊDO, 2000). Furthermore, chlorine does not reduce the microbiotic population of fruits and vegetables in more than 2 logarithmic cycles in the recommended concentrations for these purposes which can be up to $250 \mathrm{ppm}$ (BEUCHAT et al., 1998).

In several studies, different sanitizers were tested such as: organic chlorinated compounds (FANTUZZI, 2004), hydrogen peroxides (ISLAS-OSUNA, 2007), vanillin (ANTONIOLLI et al. 2004), acetic acid (FANTUZZI; PUSHAMANN; VANETTI, 2004) as alternatives to sodium hypochlorite, given that the degradation products of these sanitizers are normally acetic acid, hydrogen peroxide and water, which are less hazardous to health (BLOCK, 1991).

The cleaning and washing of these vegetables using antimicrobial solutions is essential to control the undesirable effect of these microorganisms. Inorganic chlorine derivatives, especially sodium hypochlorite, are the cheapest and most widely used compounds at the moment.

Guava is one of the most important tropical and subtropical fruits, due to its high nutritional level. Its vitamin $\mathrm{C}$ content can reach $400 \mathrm{mg} .100 \mathrm{~g}^{-1}$ of fruit, which exceeds recommendations for daily intake, surpassing the vitamin C content of oranges, limes and pineapples. Also found in guava are high levels of carotene, pro-vitamin A, thiamine, calcium, iron and phosphorous compounds (CHITARRA, 1996; IDE et al., 2001). Guava is considered an important commodity in the local economy of tropical countries as well as in the international economy, probably due to both, its minimal agricultural requirements and its high nutritional value (TAYLOR, 1993).

The purpose of the essay is to test the level of consumer acceptance of packaging used for minimally processed guava, as well as to evaluate the sanitization effect of using a chlorinated organic compound applied before and after cutting on the sensorial characteristics of the product.

\section{Materials and methods}

\subsection{Sample}

Guava (Psidium guajava L.) cultivar Paluma was the raw product used during the experiments, in a mature state of ripeness and with firm pulp, obtained from the Centro de Entrepostos e Armazéns Gerais de Pernambuco - CEAGEPEBrazil. After acquisition, the fruit was immediately taken to the Physicochemical and Sensorial Food Analysis Laboratory of the Domestic Science Department of the Federal Rural University of Pernambuco, UFRPE and subjected to evaluation.

\subsection{Consumer survey}

The first part of the research consisted of a survey in a supermarket in Recife, in order to evaluate consumer preferences regarding the type of cut and packaging of minimally processed guava in a specific area of the supermarket, displaying fruit and vegetable products. The guavas were sanitized by immersion for 15 minutes in $50 \mathrm{ppm}$ solution of the organic chlorate compound (Sumaveg), and washed with $5 \mathrm{ppm}$ solution of the same product. Next, the guavas were subjected to two different kinds of cut: in halves and in quarters, with and without the pulp. Two kinds of packaging were used: polyethylene terephthalate (PET) and extended polystyrene trays wrapped in polyvinyl chloride film (PS-PVC) totaling 8 options, with about $260 \mathrm{~g}$ of the product, which were presented to the consumer PET $-1 / 2$ with pulp, PET $-1 / 2$ without pulp, PET $-1 / 4$ with pulp, PET $-1 / 4$ without pulp, OS-PVC $-1 / 2$ with pulp, OS-PVC $-1 / 2$ without pulp, OS-PVC - 1/4 with pulp and OS-PVC - $01 / 4$ without the pulp.

Each package contained $260 \mathrm{~g}$ of the product. Eight different types of guava were exhibited, based on their cut and packaging types: peeled guava, sliced in halves, with pulp and stored in polyethylene terephthalate (PET) boxes, sizing $15 \times 15,3 \mathrm{~cm}$, and holding 260 PET ( $1 / 2 \mathrm{w} /$ pulp); peeled guava, sliced in halves, without pulp and stored in PET boxes (PET $1 / 2 \mathrm{w} / \mathrm{o}$ pulp); peeled guava, sliced in quarters, with pulp and stored in PET boxes (PET 1/4 w/ pulp); peeled guava, sliced in quarters, without pulp and stored in PET boxes (PET 1/4 w/o pulp); peeled guava, sliced in halves, with pulp, stored in extended polystyrene trays, holding $260 \mathrm{~g}$ and wrapped in a polyvinyl chloride film - PS-PVC - (PS-PVC 1/2 w/ pulp); peeled guava, sliced in halves, without pulp and stored in PS-PVC trays (PS-PVC $1 / 2$ w/o pulp); peeled guava, sliced in quarters, with pulp and stored in PS-PVC trays (PS-PVC 1/4 W/ pulp); peeled 
guava, sliced in quarters, without pulp and stored in PS-PVC trays (PS-PVC $1 / 4$ w/o pulp).

Consumers - who did not taste the product - were surveyed randomly from 3 p.m. to 8 p.m., and encouraged to answer questions about age, gender, consumption frequency, usage, and preference for type of cut and packaging.

\subsection{Experiment}

After determining the type of cut and packaging for minimally processed guava cv. Paluma, according to costumer preferences, the fruits were processed and subjected to two different sanitization procedures, before and after the slicing, as described in Figure 1.

Choosing ripe and firm fruit, the guavas were washed with potable water to eliminate any dirt. The minimal process occurred in the Physicochemical and Sensorial Food Analysis Laboratory of the Domestic Science Department of the UFRPE, in an acclimatized room at $24{ }^{\circ} \mathrm{C}$, on benches and with accessories (stainless steel knife, polyethylene plate and trays) previously sanitized with $200 \mathrm{ppm}$ of the organic chlorine compound for 15 minutes of immersion. The guavas were divided into two groups: S1 - sanitized before cutting and S2 sanitized after cutting.

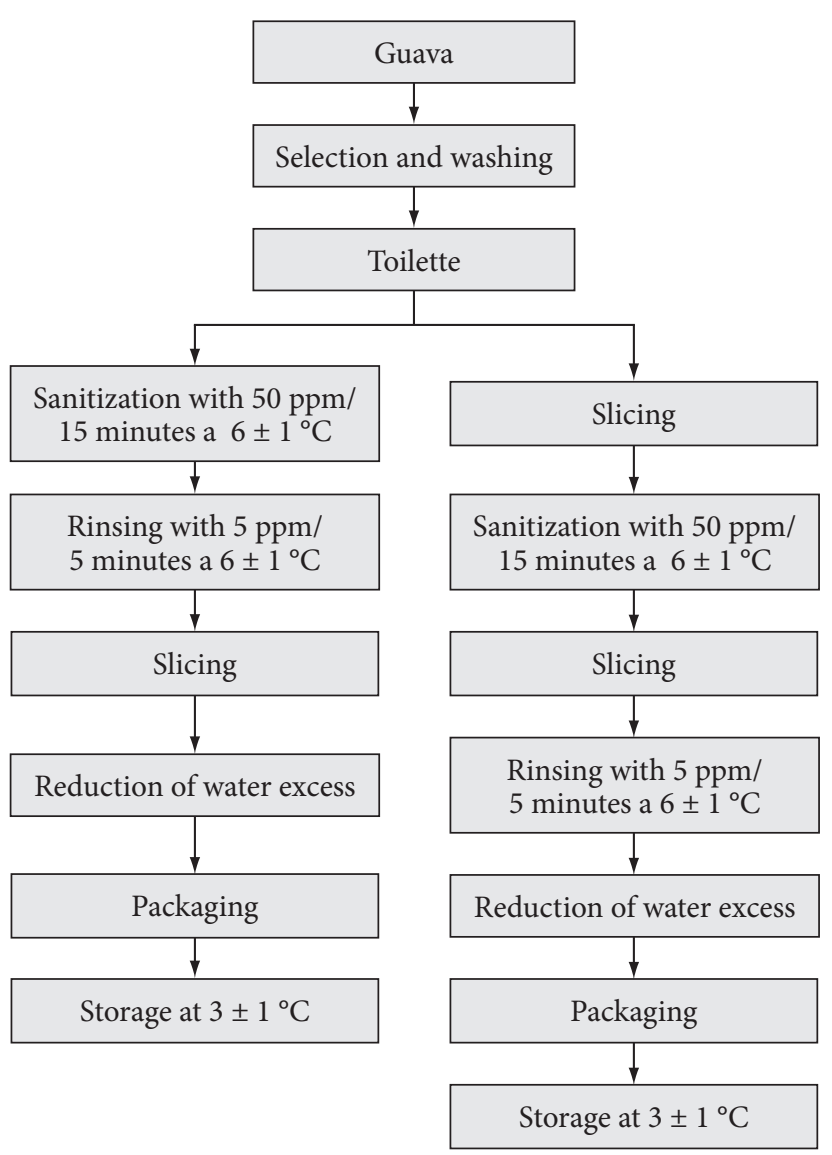

Figure 1. Flowchart describing the minimally processed guava procedures.
The S1 group - After the initial wash, the guavas were sanitized with $50 \mathrm{ppm}$ of the chlorated organic compound for 15 minutes and washed with $5 \mathrm{ppm}$ of the same chlorated compound. After that, the guavas were peeled, cut in halves with the pulp. Excess water was removed prior to being packed and stored at $3 \pm 1{ }^{\circ} \mathrm{C}$ for further analysis.

The S2 group - The guavas were first peeled and cut in halves with the pulp and then sanitized with $50 \mathrm{ppm}$ of the organic chlorated compound for 15 minutes and washed with $5 \mathrm{ppm}$ of the same chlorated compound. After that, the excess water was removed and the fruits were packed and stored at $3 \pm 1{ }^{\circ} \mathrm{C}$ for further analysis.

\subsection{Analysis}

\section{Physicochemical}

Every three days (time points 0, 3, 6 and 9), during refrigerated storage, the minimally processed guava was converted to pulp (by removing about $86 \mathrm{~g}$ from each $260 \mathrm{~g}$ tray of minimally processed guava) and the following parameters were analyzed: $\mathrm{pH}$; Total Soluble Solids (TSS); Total Titratable Acidity (TTA); Ascorbic Acid (AA) determined by a titration method using 2,6-dichlorophenolindophenol, following the AOAC method (2002); A manual fruit texture analyzer (Model FT 327) was used to determine the penetration force, with a $8 \mathrm{~mm}$ cylindrical stainless steel plunger tip expressed in $\mathrm{KgF}$; Total (TS) and Reducing Sugars (RS) - the Total and Reducing Sugars analyses were performed at time points 0,6 and 9 using the Fehling method (INSTITUTO ADOLF LUTZ, 1985).

\section{Sensorial analysis}

Sensorial analysis of minimally processed guava was performed using the ADQ method, based on the methodology described by Chaves and Sproesser (1999). It was applied during the selection and training of the judging staff and sample evaluation process.

\section{Microbiological analysis}

The microbiological analysis was carried out at the Laboratory for Experimentation and Analysis of Food (LEAAL) at the Federal University of Pernambuco (UFPE). The presence of Salmonella spp, total coliforms and Eschechiria coli was investigated only at time zero, using the ELISA technique with Salmonella vidas Biomerrieux (AOAC, 2002). In order to detect total coliforms and E. coli, the colony plate counting method was chosen, using Petrifilm $3 \mathrm{M}$ (EC) plates incubated at $35^{\circ} \mathrm{C} / 24$ hours (AOAC, 2002). Viable mesophylic aerobic bacteria were analyzed by plate counting every 48 hours (AOAC, 2002).

\section{Statistical analysis}

The experimental design was completely randomized using a factorial design of $2 \times 1 \times 1 \times 4$ (two sanitization forms, one packaging, one storage temperature and 4 evaluation periods). The results obtained were subjected to variance analysis 
(ANOVA) and the Tukey test at 5\% significance, comparing averages using SAS program for Windows 2001.

\section{Results and discussion}

\subsection{Consumers survey}

The survey was conducted among 100 consumers in a supermarket in the city of Recife, where $46 \%$ of the interviewees were males and $54 \%$ were females, with ages varying between 18 and 80 , with the majority of individuals being 30 to 48 years old (data not shown). Megale (2002), when researching minimally processed (MP) mangos consumed by customers at the Carrefour Dom Pedro-Campinas Supermarket, found the highest concentration of interviewees being of 50 years and older. According to Ragaert (2004), in a study performed among consumers of MP vegetables and fruits in a Belgian supermarket, the group that showed the highest intention of buying MP products was the one with highest educational levels, which averaged around $58.7 \%$ with more than 18 years of study.

Dantas et al. (2005) evaluating buying intentions for minimally processed collard greens in a supermarket in Viçosa-MG, also noted that in the group that showed the highest buying intention, $72 \%$ had studied to undergraduate or graduate level.

Regarding consumption frequency, it was observed that the majority of consumers questioned (46\%) consumed whole guava less than once a week and $21 \%$ consumed it at least once a week (Table 1).

The low consumption of minimally processed fruits can be attributed to low purchasing power over the past five to six years, which was a drawback for the launch of the minimally processed products segment, as it led households to purchase only traditional non-processed foods, as opposed to acquiring

Table 1. Results of a consumer survey performed in a supermarket in Recife.

\begin{tabular}{|c|c|c|c|}
\hline \multicolumn{4}{|c|}{ Whole guava consumption frequency (\%) } \\
\hline Daily & Once a week & Twice a week & $\begin{array}{c}\text { Less than once } \\
\text { a week }\end{array}$ \\
\hline 12 & 21 & 21 & 46 \\
\hline \multicolumn{4}{|c|}{ Willingness to buy (\%) } \\
\hline $\begin{array}{c}\text { Consume in } \\
\text { natura }\end{array}$ & \multicolumn{2}{|c|}{ Blended/Juice Form } & Both Ways \\
\hline 55 & \multicolumn{2}{|c|}{34} & 11 \\
\hline \multicolumn{4}{|c|}{ Type of slice (\%) } \\
\hline $1 / 2 \mathrm{w} /$ Seeds & $1 / 2 \mathrm{w} / \mathrm{o}$ Seeds & $1 / 4 \mathrm{w} /$ Seeds & $1 / 4 \mathrm{w} / \mathrm{o}$ Seeds \\
\hline 41 & 24 & 18 & 17 \\
\hline \multicolumn{4}{|c|}{ Packaging preferences (\%) } \\
\hline \multicolumn{2}{|c|}{ PET } & \multicolumn{2}{|c|}{ PS-PVC } \\
\hline \multicolumn{2}{|c|}{73} & \multicolumn{2}{|c|}{27} \\
\hline
\end{tabular}

$1 / 2 \mathrm{w} /$ seeds - Guava sliced in halves with seeds; $1 / 2$ w/o seeds - Guava sliced in halves without seeds; $1 / 4 \mathrm{w} /$ seeds - Guava sliced in quarters with seeds; $1 / 4$ w/o seeds - Guava sliced in quarters without seeds; PET - Terephthalate-polystyrene; and PS-PVC - Extended Polystyrene with Polyvinyl Chloride Film. new modern possibilities - specially the minimally processed ones (DURIGAN, 2004).

Megale (2002), evaluating the consumption frequency of minimally processed mangos, observed that $51 \%$ consumed this fruit everyday, while Ragaert (2004) observed that $57.1 \%$ of all interviewees consumed minimally processed fruits on a weekly basis and 33.4\% consumed it on a monthly basis. Dantas et al. (2005) observed that 55\% of all interviewees consumed minimally processed collard greens once a week.

The results regarding willingness to buy (Table 1) showed that $55 \%$ bought guavas whole and consumed them in natura, while $34 \%$ used the fruit to prepare drinks such as juice, and only $1 \%$ admitted to consuming them in both forms. Megale (2002) showed that $90 \%$ of consumers bought MP mango with the intention of consuming it in natura.

As described by Durigan (2004), one of the obstacles for the marketing of MP products is lack of knowledge about these products at the moment of the buying decision, since it is most usual to buy fruits in a fresh and primary form or as juices and candies.

The peeled guava sliced in halves was the choice of $41 \%$ of the interviewees (Table 1) who expressed interest in preserving the pulp so as to maintain the pleasant flavor. Amongst the individuals interviewed by Megale (2002) regarding the type-ofcut preference for minimally processed mangos, $67 \%$ preferred mango cut in slices. Antoniolli et al. (2004) also observed a preference for minimally processed pineapple cut in slices compared to the cubic cut.

Appearance and the possibility of re-use were the main reasons that led $73 \%$ of the interviewed consumers preferred the PET packaging, independently of the type of slice (Table 1 ). This result was similar to the one found by Pizarro (2003) who tested consumer preference for PET or PVC packaging of honeydew melon, and found that $71 \%$ favored the PET packaging.

Dantas et al. (2005), when researching the willingness to buy minimally processed products noted that the possibility of a better visualization of the product inside the packaging did not affect significantly the consumer's willingness to buy.

Ragaert et al. (2004), studying the attributes that influence the buying and consumption of minimally processed fruits and vegetables among consumers, observed that the general packaging appearance and transparency were important aspects considered for buying - differing from the results obtained by Aguiar et al. (2001), apud Silva et al. (2003), when researching the consumer's profile from Fortaleza, who listed weight, packaging and product composition as the most important factors to attract the consumer's attention.

Throughout the experimentation it was observed that PET packaging was not as suitable as expected. During storage at $3 \pm 1^{\circ} \mathrm{C}$ the accumulation of water condensation was observed on the packaging lid's internal surface, starting on the second day of storage - thus compromising the general appearance of the product. Therefore, another experiment was performed using a polystyrene (PS) tray with Polyvinyl Chloride (PVC) 
Film for packing the product, for the same period of time and storage conditions.

\subsection{Physicochemical analysis}

The Physicochemical analysis (Table 2) showed no significant interaction between the two types of packaging, sanitization and storage time for the $\mathrm{pH}$, TSS, TTA and TSS/TTA values on MP guavas.

The average values for the $\mathrm{pH}$ of minimally processed guavas packed in PET and PS-PVC and stored for 9 days at $3 \pm 1{ }^{\circ} \mathrm{C}$ did not show any statistical differences. The values remained between 3.65 and 4.00, remaining outside the optimal range ( $\mathrm{pH} 5$ to 7 ) for the growth of microbial species, assuming the humidity and temperature conditions were favorable (ROSA; CARVALHO, 2000).

Damasceno et al. (2005) did not observe significant changes in the $\mathrm{pH}$ of minimally processed honeydew melons, stored at $4{ }^{\circ} \mathrm{C}$ either, although when they were stored at $15^{\circ} \mathrm{C}$ there were significant losses throughout storage.

The Total Soluble Solids (TSS) values remained in a range between 8.80 and $10.53{ }^{\circ}$ Brix without significant changes (Table 2). The TTA averages remained between 0.63 and $1.10 \mathrm{mg}$ of citric acid. $100 \mathrm{~g}^{-1}$ of fruit without statistical differences (Table 2).

Damasceno et al. (2005) did not show significant losses of TSS of minimally processed honeydew melons stored at 4 and $15{ }^{\circ} \mathrm{C}$. Mattiuz, Durigan e Rossi Jr. (2003), observed a significant decrease among the TSS levels of Paluma and Pedro Sato minimally processed guavas stored in PET packaging at $3 \pm 1^{\circ} \mathrm{C}$. The average value found by these authors for $\mathrm{cv}$. Paluma was of $7.55^{\circ}$ Brix.

The values of TSS/TTA rate (Table 2) varied from 8.58 to 14.85 without any significant differences. Damasceno et al. (2005) observed a significant reduction in the TSS/TTA rate for minimally processed honeydew melons stored at $15^{\circ} \mathrm{C}$, at the end of the experiment.
Our results did not show a significant loss of AA content (Table 3) in guavas stored in PET packaging, for both sanitization processes, during the whole storage period. However, a significant variation was observed during the storage of fruits sanitized before cutting (S1) in PS-PVC packaging throughout the experiment. There was a significant reduction in the AA values on the third day of storage, while on the sixth day these levels showed an increase, however, these numbers did not differ considerably from the ones found at the beginning of the experiment.

The MP guavas showed texture reduction, without significance, after the sixth day of storage with values ranging from 1.83 to $0.7 \mathrm{KgF}$ on the last day of storage (Table 3 ). The MP guavas cv. Paluma and Pedro Sato, studied by Mattiuz, Durigan e Rossi Jr. (2003) showed significant softening during storage at $3{ }^{\circ} \mathrm{C}$, moreover, $\mathrm{cv}$. Paluma showed a more intense softening than Pedro Sato, indicating greater susceptibility to the minimal processing.

The Total Sugar (TS) and Reducing Sugar (RS) analyses were performed exclusively at the 0,6 , and 9 time points because the specialized literature shows no significant changes in these compounds when shorter storage periods of time are analyzed.

The two types of packaging, sanitization and storage period did not have statistically significant influence on the TS levels in MP guavas (Table 3). The TS average values increased beyond the sixth day of storage on the PS-PVC packaging, with average of $5.96 \mathrm{mg}$ for glucose, at time 0 , and $9.28 \mathrm{mg}$ of glucose on the last day of storage, in guavas stored in PS-PVC packaging, without any significant differences. Damasceno et al. (2005) did not find significant differences in TS levels of minimally processed honeydew melons stored at $4{ }^{\circ} \mathrm{C}$, however, when they were stored at $15{ }^{\circ} \mathrm{C}$ a significant reduction was observed throughout the experiment. The results from the RS analysis found statistical evidence of an interaction between the type of packaging, sanitization method and storage time. An increase was observed for this parameter throughout the

Table 2. Average values for minimally processed guavas in different packaging, sanitized before (S1) and after (S2) cutting and stored at $3 \pm 1{ }^{\circ} \mathrm{C}$.

\begin{tabular}{|c|c|c|c|c|c|c|c|c|}
\hline \multirow[t]{3}{*}{ Period (days) } & \multicolumn{8}{|c|}{ PET } \\
\hline & \multicolumn{2}{|c|}{$\mathrm{Ph}$} & \multicolumn{2}{|c|}{ TSS } & \multicolumn{2}{|c|}{ TTA } & \multicolumn{2}{|c|}{ TSS/TTA } \\
\hline & S1 & S2 & S1 & S2 & S1 & S2 & S1 & S2 \\
\hline 0 & 3.85 & 3.95 & 8.80 & 9.40 & 1.00 & 1.10 & 8.82 & 8.58 \\
\hline 3 & 3.65 & 3.65 & 9.05 & 9.05 & 0.95 & 0.90 & 9.95 & 10.03 \\
\hline 6 & 3.80 & 3.70 & 9.05 & 9.05 & 0.85 & 0.85 & 10.62 & 10.73 \\
\hline 9 & 4.00 & 3.95 & 9.05 & 9.25 & 0.70 & 0.90 & 12.97 & 10.27 \\
\hline 0 & 3.83 & 3.80 & 9.06 & 9.93 & 0.93 & 1.00 & 10.17 & 10.11 \\
\hline 3 & 3.90 & 3.83 & 9.73 & 8.86 & 0.83 & 0.83 & 11.68 & 10.74 \\
\hline 6 & 3.86 & 3.73 & 10.53 & 10.40 & 0.83 & 0.70 & 12.82 & 14.85 \\
\hline 9 & $3.93^{\mathrm{a}}$ & $3.83^{\mathrm{a}}$ & $9.40^{\mathrm{a}}$ & $9.26^{\mathrm{a}}$ & $0.63^{\mathrm{a}}$ & $0.83^{\mathrm{a}}$ & $15.21^{\mathrm{a}}$ & $11.26^{\mathrm{a}}$ \\
\hline
\end{tabular}

PET - Terephthalate Polystyrene; PS-PVC - extended Polystyrene with Polyvinyl Chloride film; TSS - Total Soluble Solids; TTA - Total Tritable Acidity; Interaction packaging $\times$ treatments $\times$ days statistically not significant $(\mathrm{p} \leq 0.05)$ by Tukey's test. The data represent the average and 5 repetitions. 
Table 3. Average values of chemistry determinations in minimally processed guavas packaged in PET and PS-PVC and stored at $3 \pm 1{ }^{\circ} \mathrm{C}$.

\begin{tabular}{|c|c|c|c|c|c|c|c|c|}
\hline \multirow[t]{3}{*}{ Period (days) } & \multicolumn{8}{|c|}{ PET } \\
\hline & \multicolumn{2}{|c|}{ AA $\left(m g .100 \mathrm{~g}^{-1}\right)$} & \multicolumn{2}{|c|}{ Texture $(\mathrm{N})$} & \multicolumn{2}{|c|}{ TS (\%p/p) } & \multicolumn{2}{|c|}{$\mathrm{RS}(\% \mathrm{p} / \mathrm{p})$} \\
\hline & S1 & S2 & S1 & S2 & $\mathrm{S} 1$ & $\mathrm{~S} 2$ & $\mathrm{~S} 1$ & S2 \\
\hline 0 & $37.0^{\mathrm{aB}}$ & $37.7^{\mathrm{aB}}$ & $1.8^{\mathrm{a}}$ & $1.9^{\mathrm{a}}$ & $6.0^{\mathrm{a}}$ & $6.4^{\mathrm{a}}$ & $5.6^{\mathrm{aA}}$ & $6.0^{\mathrm{aA}}$ \\
\hline 3 & $38.8^{\mathrm{aA}}$ & $31.8^{\mathrm{aA}}$ & $2.1^{\mathrm{a}}$ & $1.9^{\mathrm{a}}$ & - & - & - & - \\
\hline 6 & $31.2^{\mathrm{aA}}$ & $41.6^{\mathrm{aA}}$ & $2.3^{\mathrm{a}}$ & $1.5^{\mathrm{a}}$ & $6.0^{\mathrm{a}}$ & $5.4^{\mathrm{a}}$ & $5.5^{\mathrm{aAB}}$ & $5.2^{\mathrm{aB}}$ \\
\hline 9 & $30.0^{\mathrm{aB}}$ & $53.3^{\mathrm{aAB}}$ & $1.2^{\mathrm{a}}$ & $1.1^{\mathrm{a}}$ & $6.7^{\mathrm{a}}$ & $6.4^{\mathrm{a}}$ & $6.0^{\mathrm{aB}}$ & $5.7^{\mathrm{aB}}$ \\
\hline 0 & $85.4^{\mathrm{aA}}$ & $64.1^{\mathrm{aAB}}$ & $1.7^{\mathrm{a}}$ & $1.9^{\mathrm{a}}$ & $5.5^{\mathrm{a}}$ & $6.4^{\mathrm{a}}$ & $5.2^{\mathrm{cA}}$ & $5.6^{\mathrm{bA}}$ \\
\hline 3 & $30.6^{\mathrm{bA}}$ & $30.7^{\mathrm{aA}}$ & $1.4^{\mathrm{a}}$ & $1.9^{\mathrm{a}}$ & - & - & - & - \\
\hline 6 & $53.4^{\mathrm{abA}}$ & $42.6^{\mathrm{aA}}$ & $1.0^{\mathrm{a}}$ & $1.1^{\mathrm{a}}$ & $8.4^{\mathrm{a}}$ & $9.8^{\mathrm{a}}$ & $7.0^{\mathrm{bA}}$ & $4.2^{\mathrm{bB}}$ \\
\hline 9 & $74.3^{\mathrm{aA}}$ & $42.4^{\mathrm{aAB}}$ & $0.7^{\mathrm{a}}$ & $1.1^{\mathrm{a}}$ & $8.9^{\mathrm{a}}$ & $9.6^{\mathrm{a}}$ & $8.9^{\mathrm{aA}}$ & $9.5^{\mathrm{aA}}$ \\
\hline
\end{tabular}

S1 - sanitized before cutting; S2 - sanitized after cutting; PET - Terephthalate Polystyrene; PS-PVC - extended Polystyrene with Polyvinyl Chloride film; RS - Reducing Sugar; TS - Total Sugar; AA - Ascorbic Acid; Interaction packaging $\times$ treatments $\times$ days statistically not significant $(\mathrm{p}>0.05)$ by Tukey's test. Capital letters compare the averages among sanitizations, small letters compare the averages of the storage period. The data represent the average and 5 repetitions.

experiment, merely in minimally processed guavas stored in PS-PVC packaging for both types of sanitization processes, and, moreover, these values were higher after the sixth day of storage. Damasceno et al. (2005) also observed an increase in this feature, throughout the experiment, in minimally processed honeydew melons stored at $15^{\circ} \mathrm{C}$ (Table 3 ).

\subsection{Microbiological analysis}

Contaminations by coliforms at $45^{\circ} \mathrm{C}$, E. coli and Salmonella were not observed in minimally processed guavas (data not shown). The $50 \mathrm{ppm}$ concentration associated with the immersion technique in both treatments proved to be efficient in controlling those microorganisms independently of the packaging type (Table 4 ).

Concerning the microorganisms of the normal vegetal microbiota found in the counts for viable aerobic mesophylic microorganisms, small changes in microbial communities were observed throughout the experiments, especially when the MP guava was packed in PS-PVC. The guava from the S2 and PET packaging group showed a maximum count of $1.1 \times 10^{2} \mathrm{CFU}$, per gram of fruit (Table 4) during storage. The absence of exudates on the guavas must have accounted for the low findings of these bacteria.

In Brazil there is no specific legislation for minimally processed products, the Anvisa resolution $\mathrm{n}^{\circ} 12$, of January 2001 establishes the limit of $5 \times 10^{2} \mathrm{UFC}$ coliforms at $45^{\circ} \mathrm{C}$. $\mathrm{g}^{-1}$, for fruits, fruit products and such like - fresh, in natura, prepared that has been peeled, selected and fractioned; sanitized, refrigerated or frozen for direct consumption (BRASIL, 2001).

Arruda et al. (2004), testing different packaging for minimally processed honeydew melons stored at $3{ }^{\circ} \mathrm{C}$, observed a maximum growth of $8.3 \times 10^{3}$ when they were packaged using polypropylene (PP). Antoniolli et al. (2004) observed that for MP pineapples stored at $4{ }^{\circ} \mathrm{C}$, the mesophylic microorganism count was around $10^{3}$ and $10^{4}$ for the sliced and cubed fruit, respectively. Maciel et al. (2004) also detected growth of
Table 4. Total count of viable anaerobic mesophylic (CFU.g $\left.{ }^{-1}\right)$ microorganisms from minimally processed guava packaged in PET and PS-PVC and stored at $3 \pm 1{ }^{\circ} \mathrm{C}$.

\begin{tabular}{ccccc}
\hline $\begin{array}{c}\text { Storage } \\
\text { (days) }\end{array}$ & \multicolumn{2}{c}{ PET } & \multicolumn{2}{c}{ PS-PVC } \\
\cline { 2 - 5 } & S1 & S2 & S1 & S2 \\
\hline 0 & 20 & 10 & 0 & 0 \\
3 & $<10$ & 20 & 0 & 0 \\
6 & 20 & 90 & $<10$ & 10 \\
9 & $<10$ & $1.1 \times 10^{2}$ & $<10$ & 10 \\
\hline
\end{tabular}

S1 - sanitized before cutting; S2 - sanitized after cutting; PET - Terephthalate Polystyrene; PS-PVC - extended polystyrene with polyvinyl chloride film. Results expressed with $<10$ CFU.g ${ }^{-1}$ represent lack of growth.

mesophylic bacteria in MP mangos stored at $7^{\circ} \mathrm{C} \geq 3 \times 10^{4}$, similarly to Mattiuz, Durigan e Rossi Jr. (2003) who observed an increase in the number of colony forming units (CFU), throughout the storage period, in minimally processed guavas stored at $3{ }^{\circ} \mathrm{C}$.

Zagory (2000), described that the number and type of microorganisms present in MP products are variable and the mesophylic bacterial count in these products after processing, varies from $10^{3}$ to $10^{9} \mathrm{CFU} \cdot \mathrm{g}^{-1}$. Odumeru et al. (1997) showed that temperature control is essential to preserve the quality of minimally processed vegetables, since they found a higher count of mesophylic organisms in products stored at $10^{\circ} \mathrm{C}$ compared to products stored at $4{ }^{\circ} \mathrm{C}$.

The total mesophylic bacterial count aims to detect aerobic bacteria growing at between 15 and $45^{\circ} \mathrm{C}$. However, counting these microorganisms at low temperatures such as $3{ }^{\circ} \mathrm{C}$, for example, allows inclusion of psychrophilic bacteria in those counts and, even though there is no specific legislation for these bacteria, it is commonly accepted that food products which contain microbial counts around $10^{5}$ to $10^{6} \mathrm{CFU}^{-1}{ }^{-1}$ are considered inappropriate for human consumption due to loss 
of nutritional values, organoleptic changes, deterioration and/ or presence of pathogens (ARRUDA et al., 2004).

In this study, the mesophylic bacterial counts found in minimally processed guava showed much lower values.

\subsection{Sensorial analysis}

The sensorial profile of minimally processed guava throughout the storage period is shown in Figures 2, 3, 4 and 5. Each sensorial feature evaluated is represented by an axis that begins in the middle of the graph. The average intensity of each feature, for each day of analysis, is marked on its respective axis, with the center of the graph being the lowest intensity point on the scale used during the sensorial evaluation.

The MP guava sensorial characteristics analysis showed a significant interaction among different types of packaging, sanitization and storage time with the color and sweet taste features. A significant increase in the statistical average of those features was observed beginning on the sixth storage day for sanitized fruits after cutting (S2) and stored in PS-PVC packaging (Figure 5). No significant changes were observed in fruits sanitized before and after cutting and stored in PET packaging (Figures 2 and 3 ).

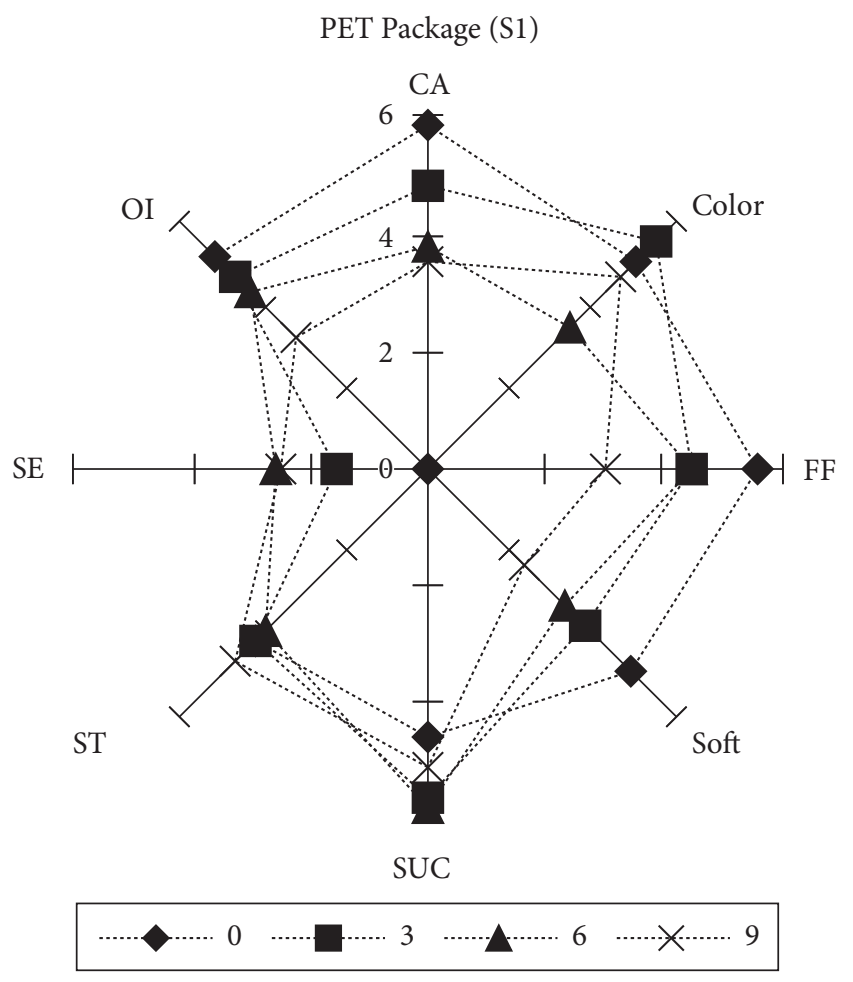

Figure 2. Graphic representation of the sensorial evaluation averages of minimally processed guavas stored in PET packaging at $3 \pm 1{ }^{\circ} \mathrm{C}$ for 9 days. PET - terephthalate polystyrene; $\mathrm{S} 1$ - sanitization before cutting; CA - characteristic aroma; FF - firm to the fork; SUC - succulence; ST - sweet taste; SE - strange taste; and OI - overall impression.

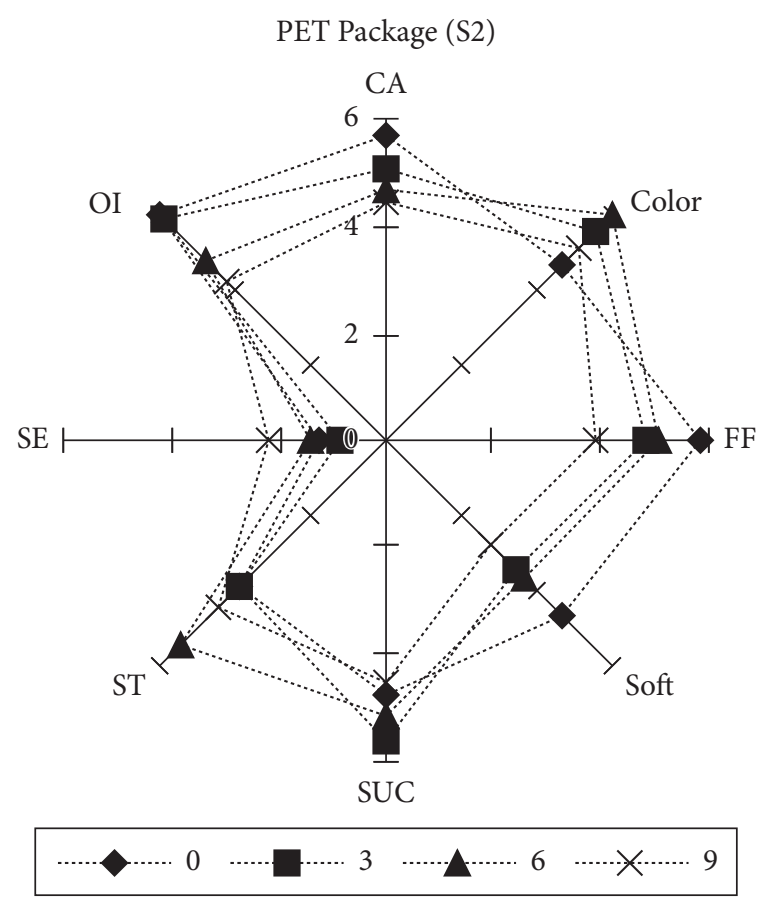

Figure 3. Graphic representation of the sensorial evaluation averages of minimally processed guavas stored in PET packaging at $3 \pm 1{ }^{\circ} \mathrm{C}$ for 9 days. PET - terephthalate polystyrene; $\mathrm{S} 2$ - sanitization after cutting; CA - characteristic aroma; FF - firm to the fork; SUC - succulence; ST - sweet taste; SE - strange taste; and OI - overall impression.

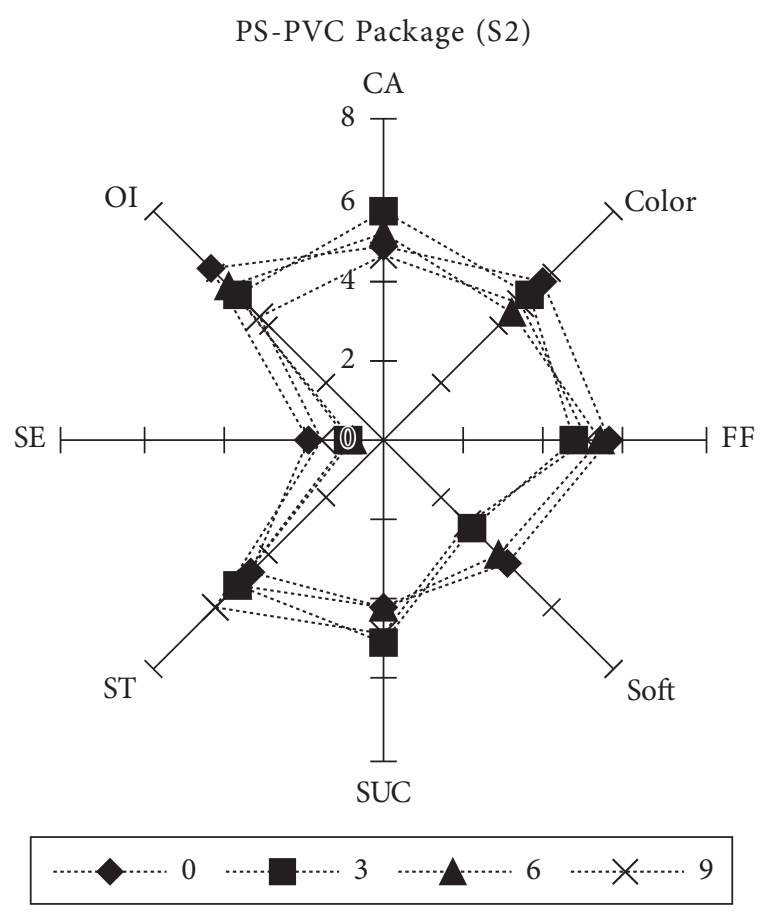

Figure 4. Graphic representation of the sensorial evaluation, averages of minimally processed guavas stored in PS-PVC packaging at $3 \pm 1{ }^{\circ} \mathrm{C}$ for 9 days. PS-PVC - polystyrene expanded with polyvinyl polyvinyl chloride; $\mathrm{S} 1$ - sanitization before cutting; $\mathrm{CA}$ - characteristic aroma; FF - firmness to the fork; SUC - succulence; ST - sweet taste; SE strange taste; and OI - overall impression. 


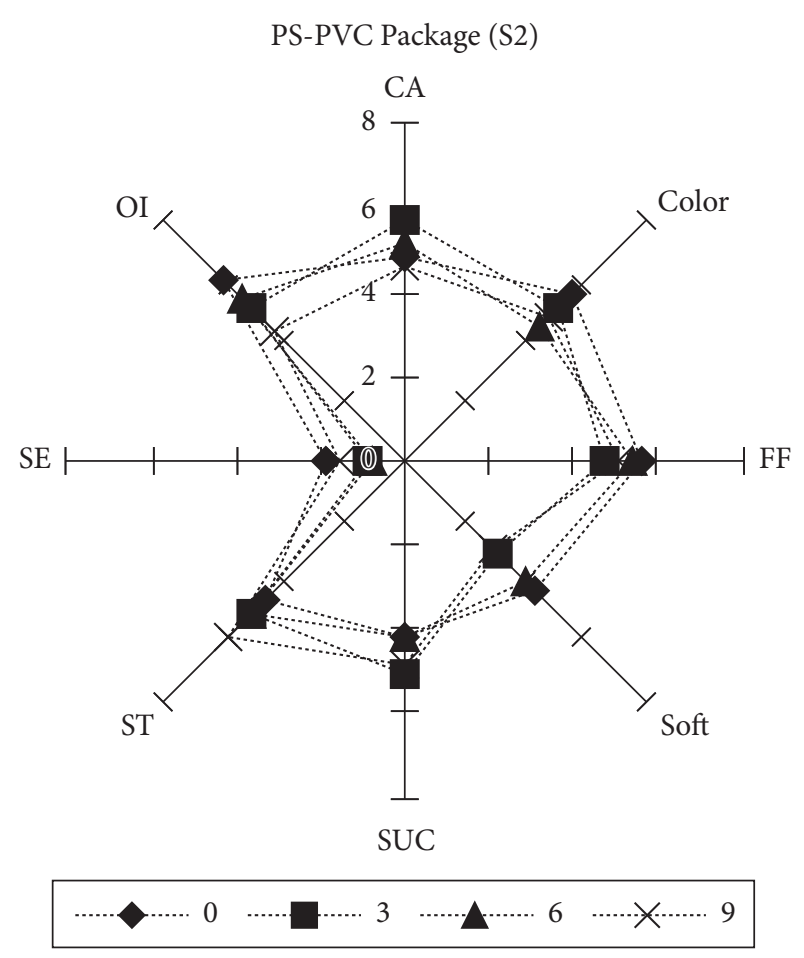

Figure 5. Graphic representation of the sensorial evaluation averages of minimally processed guavas stored in PS-PVC packaging at $3 \pm 1{ }^{\circ} \mathrm{C}$ for 9 days. PS-PVC - polystyrene expanded with polyvinyl polyvinyl chloride; S2 - sanitization after cutting; CA - characteristic aroma; FF - firmness to the fork; SUC - succulence; ST - sweet taste; SE strange taste; and OI - overall impression.

The "sweet taste" of MP guavas sanitized before cutting (S1) and stored in PET packaging (Figure 2) and those sanitized after cutting (S2) and stored in PS-PVC packaging (Figure 5), increased significantly after the sixth day of storage. Mattiuz, Durigan e Rossi Jr. (2003) found different results with MP guava cv. Paluma, they observed a significant reduction in flavor throughout the experiment. Temperatures of 3,6 and $9{ }^{\circ} \mathrm{C}$ did not influence the taste of MP papaya during storage (TEIXEIRA et al., 2001).

The "characteristic aroma" of MP guavas stored in PS-PVC packaging (Figures 4 and 5) showed statistically higher averages (5.40) than the ones packed in PET (4.22), Figures 2 and 3, on the sixth day of storage. Arruda et al. (2004) tested different packaging to store MP honeydew melons and did not notice any significant changes in the aroma feature.

The "texture" of MP guavas, evaluated by the firmness to the fork, showed statistical differences during the storage period, with a significant reduction in the average, starting on the third day of the fruits being sanitized after cutting (Figures 3 and 5). The firmness to the fork feature received statistically significant grades on sanitization after cutting (S2) when compared to the ones from sanitization before cutting (S1), during the study time.

The averages attributed to "softness" of MP guavas showed a significant reduction related to storage time. The reduction was observed starting on the third day of study. Damasceno (2005) did not show any significant differences in color and softness for MP Spanish honeydew melons, although the same author observed a decrease in the honeydew melon firmness similarly to that which Megale (2002) found for MP mangos and Teixeira et al. (2001) found for MP Formosa papayas. Ragaert et al. (2004), when researching the perception and purchasing characteristics of consumers of minimally processed fruit and vegetables, noticed that the higher grades credited to sensorial characteristics such as flavor, aroma and texture were possibly due to previous familiarity with the product.

The grades attributed to "succulence" of the MP guavas stored in PET packaging, were statistically higher than those attributed to PS-PVC packaging. The succulence ascribed to the MP guavas in PET packaging is possibly related to the accumulation of water condensation in the cited packaging.

Considering the "strange taste" characteristic, the S2 group conferred an unpleasant taste on the samples on the first day of storage in PS-PVC packaging, which was observed for PET packaging only after the ninth storage day (Figures 2, 3, 4 and 5).

The overall quality of minimally processed guavas evaluated by the "overall impression" feature, showed a significant decrease associated with storage time. The decrease was observed from the third day until the end of the experiment. However, it was evident that the fruits stored in PS-PVC packaging were in better condition than fruits stored in the PET packaging. These results are similar to those found by Arruda et al. (2004) for minimally processed honeydew melons stored at $3{ }^{\circ} \mathrm{C}$, which also presented a decline in appearance when different types of packaging were tested (multilayer film BB-200; polyolephinic film and polypropylene film).

\section{Conclusions}

The results achieved in this study allow us to conclude that consumers showed a preference for guava cut in equatorial halves with pulp, stored in PET packaging. Although this type of packaging was not the most adequate for storage of minimally processed guavas because it facilitated the accumulation of water droplets on the lid of the package, compromising the general appearance of the product.

The two different sanitization processes and the two types of packaging did not have a statistically significant influence on the $\mathrm{pH}$, TSS, TTA, TSS/TTA, texture and AA values. An increase in the reducing sugar levels was observed during storage in PS-PVC. The two sanitization treatments were equally efficient in avoiding contamination according to microorganism indicators of sanitary conditions. Furthermore, the sanitization before cutting the fruit was the most efficient method of controlling the growth of viable mesophylic microorganisms.

Minimally processed guava cv. Paluma can be stored in PS-PVC packaging and remain in good consuming conditions for 6 days when stored at $3{ }^{\circ} \mathrm{C}$. 


\section{Acknowledgements}

We would like to thank $\mathrm{CNPq}$ (National Council for Scientific and Technological Development) for its financial support and Johnson Diversey for providing the necessary products for the sanitization.

\section{References}

AHVENAINEM, R. New approaches in improving the shelf life of minimally processed fruit and vegetables. Trends in Food Science \& Technology, v. 7, n. 6, p. 179-187, 1996.

ANTONIOLLI, L. R. et al. Avaliação da vanilina como agente antimicrobiano em abacaxi "pérola" minimamente processado. Ciência e Tecnologia de Alimentos, v. 24, n. 3, p. 473-477, 2004.

ARRUDA, M. C. et al. Conservação de melão rendilhado minimamente processado sob atmosfera modificada ativa. Ciência e Tecnologia de Alimentos, v. 24, n. 1, p. 53-58, 2004.

BRASIL. Agência Nacional de Vigilância Sanitária. Resolução RDC n. 12, de 2 de janeiro de 2001. Regulamento técnico sobre padrões microbiológicos para alimentos. Diário Oficial da União, Poder Executivo, Brasília, DF, 10 de janeiro de 2001.

BRECHT, J. K. Physiology of Lightly Processed Fruit and Vegetables. HortScience, v. 30, n. 1, p. 18-22, 1995.

CARVALHO, A. V.; LIMA, L. C. O. Modificações de componentes da parede celular e enzimas de kiwis minimamente processados submetidos ao tratamento com ácido ascórbico, acido cítrico e CaCL2. Revista Brasileira de Fruticultura, v. 22, n. 3, p. 386-390, 2000.

CHITARRA, M. I. F. Goiaba para exportação: procedimentos de colheita e pós-colheita características das frutas de exportação. Brasília: EMBRAPA, 1996. (Série publicações técnicas FRUPEX, 35).

DAMASCENO, K. S. F. S. C. et al. Melão minimamente processado: um controle de qualidade. Ciência e Tecnologia de Alimentos, v. 25, n. 4, p. 651-658, 2005.

DANTAS, M. I. S. et al. Avaliação da intenção de compra minimamente processada. Ciência e Tecnologia de Alimentos, v. 25, n. 4, p. 762-767, 2005.

DI PENTIMA, J. H. et al. Estudio del comportamiento de vegetales listos para usar, envasados con diferentes láminas plásticas. La Alimentación Latinoamericana, n. 213, p. 46-50, 1996.

DURIGAN. J. F. Panorama do processamento mínimo de frutas. In: ENCONTRO NACIONAL SOBRE PROCESSAMENTO MÍNIMO DE FRUTAS E HORTALIÇAS, 3, 2004, Viçosa. Anais... Viçosa: UFV, 2004. p. 9-12.

DURIGAN. J. F. O processamento mínimo de frutas. In: CONGRESSO BRASILEIRO DE FRUTICULTURA, 16, 2000, Fortaleza. Anais... Fortaleza: Sociedade Brasileira de Fruticultura, 2000. 12 p.
IDE, D. C. et al. Cultura da goiaba: perspectiva, tecnologias, viabilidades. Niterói: PESAGRO-RIO, 2001. 36 p. (Documentos, 72).

INSTITUTO ADOLF LUTZ - IAL. Normas analíticas, métodos químicos e físicos para análise de alimentos. 3 ed. São Paulo, 1985. 533 p. (v. 1).

KADER, A. A. Pineapple: recommendations for maintaining postharvest quality. California: University of California, 2006. Disponível em: <http://postharvest.ucdavis.edu/produce/ ProduceFacts/Fruit/pineapple.shtml>. Acesso em: 8 set. 2009.

MACIEL, M. I. S. et al. Quality evaluation of minimally processed mango cv. "espada". Acta Horticultural, n. 645, p. 261-265, 2004.

MEGALE, J. Influência do estádio de maturação e da condição de armazenagem em parâmetros sensoriais, químicos e microbiológicos de manga, cultivar palmer semi-processada. 2002. 98 p. Dissertação - (Mestrado) - Universidade Estadual de Campinas - UNICAMP, Campinas.

MATTIUZ, B. H.; DURIGAN, J. F.; ROSSI JÚNIOR, O. D. Processamento mínimo em goiabas "Paluma e "Pedro Sato": avaliação química, sensorial e microbiológica. Ciência e Tecnologia de Alimentos, v. 23, n. 3, p. 409-413, 2003.

ODUMERU, J. A. et al. Assessment of the microbiological quality of ready-to-use vegetables for healh-care food services. Journal of Food Protection, v. 60, n. 8, p. 954-960, 1997.

PIZARRO, C. A. C. Avaliação de melão minimamente processado em diferentes temperaturas e embalagens. 2003. 70 p. Dissertação (Mestrado em Engenharia Agrícola) - Universidade Estadual de Campinas - UNICAMP, Campinas.

RAGAERT, P. et al. Consumer perception and choice minimally processed vegetables and packaged fruits. Food Quality and Preference, v. 15, n. 3, p. 259-270, 2004.

ROJAS-GRAÜ, M. A.; TAPIA, M. S., MARTIN-BELLOSO, O. Empleo de recubrimientos comestibles en frutas frescas cortadas: nuevo enfoque de conservación y desarrollo de productos. Alimentaria, n. 382, p. 105-118, 2007.

ROSA, O. O.; CARVALHO, E. P. Características microbiológicas de frutos e hortaliças minimamente processados. Boletim da Sociedade Brasileira de Ciência e Tecnologia de Alimentos, v. 34, n. 2, p. 84-92, 2000.

SILVA, N. et al. Ocorrência de Escherichia Coli O157:H7 em vegetais e resistência dos agentes de desinfecção de verduras. Ciência e Tecnologia de Alimentos, v. 23, n. 2, p. 167-173, 2003.

TAYLOR, J. E. Biochemistry of fruit ripening. [S.l.]: Chapman \& Hall, 1993. 454 p.

TEIXEIRA, G. H. A. et al. Processamento mínimo de mamão Formosa. Ciência e Tecnologia dos Alimentos, v. 21, n. 1, p. 47-50, 2001.

ZAGORY, D. Controlled and modified atmospheres: advances in MAP. In: Postharvest Technology. Fresh-cut: maintaining quality and safety. California, 2000. p. 4-5. 